Centers for Disease Control, 1968-1979. JInfect Dis 1981;143:743746.

23. Gellert GA, Waterman SH, Ewett D, et al. An outbreak of acute gastroenteritis caused by a small round structured virus in a geriatric convalescent facility. Infect Control Hosp Epidemiol 1990;11:459-464.

24. Swayer LA, Murphy JJ, Kaplan JE, et al. 25 to $30 \mathrm{~nm}$ virus particle associated with a hospital outbreak of acute gastroenteritis with evidence of airborne transmission. Am J Epidemiol 1988;127:1261-1271.

25. Ho M-S, Glass RI, Monroe SS, et al. Viral gastroenteritis aboard a cruise ship. Lancet 1989;ii:961-965.

26. Crozier D, Woodward TE, Armed Forces Epidemiological Board. Activities of the commission on epidemiological survey, 1961. Milit Med 1962;127:701-705.

27. Clemmer DI, Hickey JLS, Bridges JF, Schliessmann DJ, Shaffer ME Bacteriologic studies of experimental airborne salmonellosis in chicks. I Infect Dis 1960;106:197-210.

28. MacKenzie CR, Livingstone DJ. Salmonellae in fish and food. $S$
Afr Med J 1968;42:999-1003.

29. Rubbo SD. Cross-infection in hospital due to Salmonella derby. Journal of Hygiene 1948;46:158-163.

30. Rubenstein AD, Fowler RN. Salmonellosis of the newborn with transmission by delivery room resuscitators. Am J Public Health 1955;45:1109-1114.

31. Neter E. Observations on the transmission of salmonellosis in man. Am J Public Health 1950;40:929-933.

32. Weinstein S, Gantz N, Pelletier 0, Hilbert D. Bacterial surface contamination of patients' linen: isolation precautions versus standard care. Am J Infect Control 1989;17:264-267.

33. Pugliese G, Hunstiger CA. Central services, linens, and laundry. In: Bennett JV, Brachman PS, eds. Hospital Infections. Boston, MA: Little, Brown, and Co; 1992:335-344.

34. Centers for Disease Control. Guideline for handwashing and hospital environmental control, 1985. Infect Control 1986;7:231242.

\title{
Lab Errors Responsible for Some False-Positive Multidrug- Resistant TB Cases During Outbreaks
}

\section{by Gina Pugliese, RN, MS Medical News Editor}

Since 1990, the Centers for Disease Control and Prevention (CDC) has investigated multidrugresistant tuberculosis (MDR-TB) outbreaks in which some of the patients were thought to have falsely positive MDR Mycobacterium tuberculosis (Mtb) cultures. Of 223 patients reported to have MDR Mtb isolates, a record review found evidence that 62 (28\%) did not have MDR-TB. These reports came from at least 16 hospitals and laboratories in five states. Fifty-eight had a clinical course inconsistent with TB, with many smear and culture negative specimens but only one cul- ture positive for MDR-TB, and showed clinical improvement with no antituberculosis treatment. The other four contaminated specimens came from patients with drug susceptible TB; three patients each had one MDR isolate reported among multiple susceptible specimens and the fourth was a child reported with MDR-TB but whose only exposure was to a relative with susceptible TB.

Laboratory procedure review suggested that contamination occurred both during primary isolation and when susceptibilities were done. Most of the 62 contaminated specimens were processed by Bactec shortly after highly smear-positive MDR isolates from patients who had multiple positive specimens. These data suggest that contamination of isolates in TB laboratories may be common and that healthcare providers should consider the clinical course of the patient when evaluating the results of mycobacterial cultures and susceptibility testing. Laboratories should avoid contamination and should periodically evaluate their procedures to determine if contamination may be occurring.

FROM: Valway S, Dooley S, Ikeda RM, et al. Multidrugresistant TB outbreaks: false positive diagnoses of MDR-TB. 33rd Interscience Conference on Antimicrobial Agents and Chemotherapy; New Orleans, LA; October 17-20, 1993. Abstract 603. 